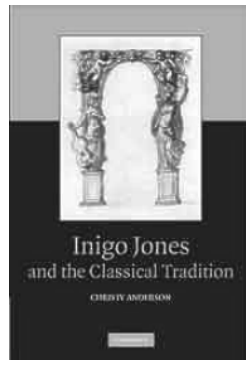

Keywords: Inigo Jones, Andrea Palladio, English neo-Classicism,
Book Review

\section{Christy Anderson}

\section{Inigo Jones and the Classical Tradition}

New York: Cambridge University Press, 2007

Reviewed by Sarah Clough Edwards

Baffy Cottege, Rosebery Road

West Runton, Norfolk NR279QW UK

sarah@talltrees84.freeserve.co.uk

As a key figure in English architectural history, Inigo Jones has already been the subject of considerable scholarship and publication. Christy Anderson's book, however, ably demonstrates the value of giving further consideration to well-studied and well-known figures. Whilst ostensibly a text about Inigo Jones, the underlying theme of the book is the evolution of an architect in seventeenth-century England, his persona, his training and his legacy. This is a fascinating notion, and one that reveals a wealth of information regarding the availability of mathematical and architectural texts and the pursuit of knowledge in the early seventeenth century.

The book is divided into seven chapters, each addressing a theme related to the overall discussion of Jones, his education and his architecture. This format results in a certain amount of overlapping in the text; the subject of measurement, for example, is raised in a number of chapters, as is the discussion of the link between Jones and the architect Andrea Palladio. The layout of the book is such, however, that whilst the text can be read from beginning to end in the traditional manner, the work does not adhere so strongly to a linear chronology that selective reading is impossible.

Chapter One, "Books and Buildings", is an introduction to the premise of the book and provides a guide to the many texts that formed the basis of an architect's knowledge. These works spanned the fields of science, mathematics, geometry, music and literature as well as architecture itself, and were written in a number of European languages. The introduction makes clear that the key to Jones's success was his scholarship, and that this scholarship went beyond that of his contemporaries.

The following three chapters concentrate on the library of architectural, mathematical and scientific texts accumulated by Jones, and examine the way he employed and understood these works. In Chapter Two, "The Famous Mr Jones", Anderson considers Jones's pursuit of fame and the importance of key patrons in his early career, whilst also examining his early architectural commissions and designs. Anderson demonstrates the importance of Jones in developing the notion of the gentleman architect, underlining that Jones worked hard to create and promote a particular image. For this reason, however, the experience and education of Jones set him apart from English architects in general. Chapter Three, "Building a Library", underlines the importance of accumulating books in the seventeenth century and the difficulties faced in collecting such texts. In addition to a book 
collection, architects also required various, and highly expensive, tools employed for the survey and measurement of sites and structures. For this reason a wealthy patron was another vital element for an architect's professional development. Chapter Four, "Conversations with the Dead", examines the way in which Jones used the text of Palladio and other architectural writers in conjunction with first-hand study of architecture. This discussion considers the importance of measurement to the architect in his study of the architecture of others, and the way in which such information was recorded.

Chapter Five, “The Hand of Inigo Jones”, comprises an examination of handwriting technique and the transmission of information and ideas through the writing and drawing of Jones. It also considers the dialogue between the living Jones and the dead Palladio through Jones's annotation of Palladio's text. Chapter Six, "A More Masculine Order", examines Jones's quest to find an architectural style which embodied the best of his predecessors' and mentors' work, gleaned from their texts and architectural output, but which also demonstrated a new, idiosyncratic, and English style. This pursuit underlines the fact that whilst Jones drew extensively on the work of Palladio, at no time was his work simply a regurgitation of Palladian models. Palladian principles can be easily discerned in the work of Jones, particularly in the modular design of the Banqueting House, yet other designs by Jones, such as that for the termination to the tower of Old St Paul's Cathedral, may contain Palladian elements such as serliana but could never be mistaken for a Palladian work. Chapter Seven, "Practices", charts the relationship between books and buildings in the work of Jones, examining the process by which an architect's theoretical studies are translated into working practice. This chapter contains detailed studies of three Jones projects, The Banqueting House and Whitehall Palace, Old St Paul's Cathedral, and Covent Garden.

The conclusion of the text considers the legacy of Jones and his importance as a figurehead in the development of the English neo-Classical and Baroque. Anderson's discussion underlines the pivotal importance of Jones in the development of the English neo-Classical style. Jones's legacy, in part, lay in the fact that having travelled to Italy and spoken to those who knew Palladio personally, he could be regarded as a direct link between the Italian architect and the English neo-Classical style. In this sense, Anderson argues, the figure of Jones provided a line of direct descent between England and Italy.

One of the achievements of this book is its demonstration that to consider the architecture of Inigo Jones solely in relation to that of Palladio is to do a great disservice to the English architect. Jones studied extensively in Italy, examining the work of many architects in great detail and giving due consideration to the writings of Alberti, Serlio and others. The fraction of Jones's library which survives is evidence of the breadth of his scholarship and the many influences on his artistic development. That said, Palladio remains the central figure of influence in Anderson's text, and certainly less discussion is given to other influential architects, such as Michele Sanmicheli and Giulio Romano.

Whilst mathematical measurement is central to the theme of the text, and was central to the architectural prowess of Jones, the process of learning and undertaking mathematical measurement is not examined in the same detail as is the acquisition of knowledge through reading and on-site examination. Whilst it is noted that Jones employed the geometrical square, for example, no further information regarding this device is provided. This is regrettable, since the depth of information regarding literary sources for Jones would have been enhanced by a parallel description of the tools of the trade. Jones kept lists of building

200 SARAH ClOUgH EDWARDS - Review of Inigo Jones and the Classical Tradition by Christy Anderson 
measurements he had taken, in his copy of Palladio's Quattro Libri. Anderson provides a section of these measurements, and it is interesting to note the paradox of Jones carefully recording distances measured in the less than accurate medium of paces. This difficulty in obtaining accurate measurements was compounded by the disparity between English measurements and the various Italian systems of measurement such as Roman palms and Venetian feet. This complexity of measurement is a subject not fully addressed in this text.

Overall, Anderson makes very clear the massive importance of the written word in the pursuit of knowledge, and architectural skill, in the seventeenth century. For this reason it is surprising that Anderson does not question the fact that Jones himself did not seek to immortalise his work in an architectural treatise similar to the Quattro Libri of Palladio. This book acknowledges that among his predecessors and contemporaries Ingio Jones stood apart, in that no other 'so closely linked their activities as designers with reading and the study from books'. It is evident that scholarship was of fundamental importance to Jones and yet, despite a personality described by a contemporary as 'conceited and boastful', he did not formalise his theories for future generations. Perhaps the best answer to this question is that Jones saw his constructed architecture as his legacy. It is fascinating to learn that Jones's words were held in such regard that already by 1715 Giacomo Leoni sought to publish a transcript of Jones's annotations to the Quattro Libri in conjunction with the Quattro Libri itself. This project was never properly brought to fruition, but the illustrations within Anderson's text of some of these annotated sheets are fascinating and a clear demonstration of the value of such an undertaking.

Although this text does not examine the architecture of Jones, ultimately its primary purpose is to provide an analysis of what Jones thought about architecture, how he developed designs, and an examination of the origins of his ideas and theories. The central theme, which addresses the library of Jones and the pursuit of knowledge through the available literature of the era, is compelling and provides insight into the commitment and scholarship of Jones himself. In this work Anderson has constructed a fascinating historical text that provides much insight into the world in which Inigo Jones lived and worked.

\section{About the reviewer}

Sarah Clough Edwards received her Ph.D. in architecture history from the University of Reading. She is now associated with the University of East Anglia, where she lectures on architectural history. Her Ph.D. research concerned the design of the convent of S. Chiara in Urbino and its architect, Francesco di Giorgio Martini of Siena. Several articles drawn from this research are now in the process of being published. Her current research is concerned with the architectural evolution of the staircase in the Renaissance period and its symbolic utilisation within the complex social mechanisms of the Italian courts. Edwards has also presented a number of conference papers on her research. 